\title{
Who brings the heat? - From municipal to diversified ownership in the Swedish district heating market post-liberalization
}

\author{
Dick Magnusson
}

Journal Article

\section{Tweet}

N.B.: When citing this work, cite the original article.

Original Publication:

Dick Magnusson , Who brings the heat? - From municipal to diversified ownership in the Swedish district heating market post-liberalization, Energy Research \&amp; Social Science, 2016. 22(), pp.198-209.

http://dx.doi.org/10.1016/j.erss.2016.10.004

Copyright: Elsevier

http://www.elsevier.com/

Postprint available at: Linköping University Electronic Press

http://urn.kb.se/resolve?urn=urn:nbn:se:liu:diva-133856

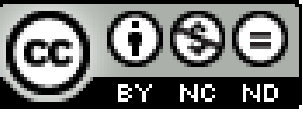




\section{Who brings the heat? - From municipal to diversified ownership in the Swedish district heating market post-liberalization}

\section{Abstract}

District heating in Sweden has undergone changes in recent decades. Parallel with transition towards sustainability, a considerable ownership restructuring has occurred, due to liberalization of energy markets. The aim of this paper is to describe and analyze trends of mergers and acquisitions in the Swedish district heating market. A systematic review of ownership in 290 municipalities has been performed through annual reports, press releases, websites, municipal minutes, newspaper articles and personal contacts. The paper shows a transformation from municipal to diverse ownership, decreased municipal ownership and increased internationalization. The window of opportunity provided by liberalization was used especially by the "big three" (E.ON, Fortum and Vattenfall) in order to strengthen market position early in the wave of acquisitions. The time period 1996-2005 was especially hectic, showing strategies of cherry picking hot spots for acquisitions, with the "big three" being responsible for a large proportion of these. The period after 2006 showed trends of companies selling several district heating businesses at once, through large-scale disinvestment. The paper shows a transformation of the district heating regime, first as a reaction to changes on the electricity market and later in its own right, raising concerns regarding the weak position of customers.

\section{Keywords}

District heating; Sweden; mergers \& acquisitions; sociotechnical change 


\section{Introduction}

District heating $(\mathrm{DH})$ and combined heat and power (CHP) are seen as important bricks in the transition towards efficient fossil-free energy systems in the EU through the Cogeneration Directive and the Energy Efficiency Directive (EC, 2004; 2012), and in Sweden through e.g. the Climate and Energy bill (Government bill 2008/09:162). DH in Sweden is often referred to as an important climate measure, as a fuel substitution from essentially $100 \%$ oil to a fuel mix of less than $10 \%$ of annual production has taken place in recent years (Di Lucia \& Ericsson, 2014).

In regards to GHG emissions the DH development and fuel substitution have been important, but equally important are processes of liberalization and privatization, especially in relation to local power, governance structures and from a user perspective. As identified by Sovacool (2014), governance structures are crucial for handling energy problems and how sociopolitical configurations and transformations influence energy decisions and broadening of roles for nonstate, and additionally non-public, actors to becoming involved in decisions on energy. This paper focuses on ownership changes in the district heating sector in Sweden, arguably a system to a large extent taken for granted until around 2000, as effects of the changed political economy started to emerge, and thus a broadening of governance structures as a shift from public, municipal ownership towards a diversified structure involving private, state, international and public-private actors along the municipal.

The electricity market was deregulated in 1996 (Sataøen et al., 2015), as competition was introduced in production and sale. The DH market was commercialized (cf. Graham \& Marvin, 2001), as DH companies were to be run on market principles and pricing rather than previous self-cost price, but without competitive elements. Put bluntly, market pricing in natural monopolies was introduced, and increased prices in Stockholm and Uppsala led to protests and subsequent national investigations (Palm \& Magnusson, 2009; Rutherford, 2008). Westin and 
Lagergren (2002, p. 595) argue that: "The lack of comprehensive discussions about the impacts on district heating prior to the reformation of the electricity markets in 1996 is astonishing." Their conclusion was that DH at that point had never been treated in its own right, and was always secondary to the far more interesting, for policy-making economists, electricity market.

Studies have previously focused on ownership changes in the electricity market (Bladh, 2002), but the total DH market has not been scrutinized previously. A significant difference between the two markets is the customers' weak position through lock-in effects in the DH market. There is a need to understand how the market changed through the transformative mergers and acquisitions (M\&As) that took place from the mid-1990s and on, forming a new regime for $\mathrm{DH}$.

As most studies on liberalizations, Swedish or international, have focused on electricity (Lee, 2004; Midttun, 1995; Sioshansi, 2006, 2008), on liberalization of infrastructure in general (Newbery, 1999) or on water services (Moss, 2008; Naumann \& Bernt, 2009), DH has not been studied to the same extent. By studying the movements from municipal ownership to diverse ownership with substantial private actors on a macro level there are opportunities to unpack trends and patterns in strategies.

This paper does bring additional light to the success story that Swedish DH is often perceived as, especially considering the low-carbon transition that has taken place in recent decades. Di Luca and Ericsson (2014) showed how the oil-regime in DH collapsed after the oil crises in the 1970's and how policies and initiatives from private and public actors lead to starting a new regime, based on biomass. Silveira and Johnson (2016) showed how integration of energy systems with different systems, such as forestry and waste management, was important for the energy transition in Sweden, as well was attention from important interest groups. They further emphasize coordination between national and local levels, and as this paper will show, the 
ownership has under the same time period changed from predominantly municipal to a diversified ownership.

As DH is considered a viable option for heating in Europe, the European Commission mentions it in the visions and goals for the recent EU strategy on heating and cooling (EC, 2016), and studies have identified the European potential for DH to be substantial through e.g. surplus use from industry, power plants and waste incineration. Understanding the analysis from a Swedish perspective is thus interesting in order to understand an historical development, and to learn from the paths taken. Energy markets in the EU have also become interconnected physically through e.g. the NordPool market, but also through ownership. As Kungl (2015) has shown, Swedish Vattenfall expanded in Europe by acquiring energy companies and DH systems, while German E.ON did the same thing in Sweden. Understandings of the effects of liberalization and internationalization of ownership is thus relevant across national borders.

The aim of this paper is to describe and analyze the trends of M\&As in the Swedish DH market. The paper thus does have a descriptive aim, in order to establish the changes and current structure of the market, but behind these results several trends are identified, which point to deeper analyses and further studies. Research questions are the following:

How has the ownership structure changed on the Swedish DH market?

What trends in ownership changes can be identified?

How can these trends and changes be understood in relation to sociotechnical change?

\subsection{Methods and material}

In order to examine past and present ownership of Swedish DH companies, all municipalities (290 in total) have been analyzed through a systematic review. The following aspects have been mapped: ownership in May 2014, time of eventual ownership changes, time of eventual 
remunicipalisation (i.e., return to municipal ownership) as well as political governance at the time. Material used for this have been annual reports, press releases, websites from municipalities and energy companies, municipal minutes and newspaper articles. On some occasions contacts have been made with municipalities and energy companies for clarification.

This paper is based on a previously published report. Due to space concerns, for full reference list covering all ownership changes, see Magnusson (2015). The quantity of material read is as follows: 56 annual reports, 12 personal contacts, 154 websites for energy companies and municipalities, 75 newspaper articles, 17 municipal documents (minutes or plans) and 21 press releases. In these totals, websites and other sources confirming that energy companies remain municipally owned are not included.

\subsection{District heating in Sweden}

DH holds a strong position on the Swedish heating market, producing $58 \%$ of the total energy use in dwellings and non-residential premises and more than $80 \%$ of the total area in the multidwelling market (SEA, 2014). This started in the late 1940s and had a strong development due to a number of factors: initial municipal focus on building distribution systems in order to obtain heat sinks for future CHP; a national public housing program from 1965-1974 with the aim to build one million dwelling units where $\mathrm{DH}$ was installed to a large extent; a national energy policy program to reduce oil dependency during the 1980s; and national policy program to reduce GHG emissions starting in the 1990s (Werner, 2007). In comparison with e.g. the UK, a country with small share of $\mathrm{DH}$ although with increasing interest, the strength for Scandinavian countries has been solid local organization and an integrated approach to infrastructure establishment and development (Bolton \& Foxon, 2013; Hawkey, Webb, \& Winskel, 2013). DH in Sweden developed under principles of self-cost price and public ownership, and energy and DH in particular were to a large extent arguably seen as a common good. 


\section{Previous studies}

In this section I will present previous studies used in order to understand the ownership changes in the Swedish DH sector.

\subsection{Liberalization on the energy market}

Liberalization of energy markets and infrastructures has been done with aims of lower prices and higher efficiency, but studies have shown some unwanted effects. Liberalization of the electricity market in the US (see Sioshansi, 2008) did not show the expected effects, as misguided market designs, inattentive implementation or political resistance led to the need for substantial subsequent adjustments and fine-tuning of the regulations. Fuel prices have increased in parallel with liberalization and Sioshansi (2008, p. 77) argued that "Restructuring did not make matters worse, nor did it result in significantly lower prices as were often promised." He further argued that many states showed rate shocks when original price freezes were lifted, exposing customers to higher prices. California's electricity crisis in 2000-2001 is stated to be a direct effect of the liberalization process (Cicchetti, Dubin, \& Long, 2004). Graham and Marvin (2001, cf. Guy et al, 1997; 1999) found traces of changed business logics post-liberalization among British infrastructure service providers, with focus on profit orientation, cherry picking of lucrative customers and demand-side management. Monstadt (2007) studied how governance in Berlin changed after privatization of the public utility and found that the main tasks of urban and regional policy have changed, as have the ways public responsibility for energy supply is exercised. Urban policy or public duties have not lost significance but the main challenges concerned inter-policy coordination, regional cooperation and private sector participation in policy planning and reconfiguration of institutional arrangements. 


\subsection{Logics of mergers and acquisitions}

The strategies and logics behind M\&As vary from sector to sector. In their review article Haleblian et al. (2009) studied the research in accounting, economics, finance, management and sociology in order to understand the antecedents of acquisitions, internal and external factors that moderate acquisition performance and other acquisition outcomes. The logics behind acquisitions fall into four categories: value creation, managerial self-interest, environmental factors and firm characteristics. Value creation concerns e.g. market power, even though limited evidence supports this; efficiency; and resource redeployment in order to generate economies of scale. The main assumption is that acquisitions are made to maximize shareholder value. Other research suggests that managerial self-interest is a driver as higher CEO compensation shows higher acquisition activity as well as managerial hubris in the form of exaggerated self-confidence in the ability to generate returns and thus overpay target companies. Environmental factors have been evident as environmental uncertainty has had a dampening effect on acquisitions. Firm characteristics have an effect, as acquisition experience increases the likelihood of further acquisitions.

Haleblian et al. (2009) further summarize that moderators of acquisitions are associated with managerial experience and personality, and that some evidence suggests the importance of historical performance as acquisition performance tends to increase when high-performing firms couple with low-performing targets. Firm size also has an effect as some studies point to large mergers showing positive post-acquisition results due to increased asset and employee productivity, and enhanced customer attraction. Studies of effects from different acquisition waves have shown importance of moving early during the waves.

Kungl (2015) analyzed strategies and activities of Germany's leading energy companies in response to liberalization, which to a large degree have connections to the Swedish development. Three phases were identified: growth and focus on core business (1998-2005); 
pressure to grow in the face of limited opportunities (2005-2011); and crisis and reorientation (2011-2013). The four main actors strengthened their position during the first phase through acquisitions of companies outside of their former service areas, first within Germany, and later internationally. E.ON expanded to Sweden, Great Britain and Eastern Europe, while Swedish Vattenfall expanded to the German market. Focus was not on expanding production capacities, but on acquiring other companies. During the second phase, the number of acquisitions declined but the ones that were made proved to be bad investments, e.g. Vattenfall bought Dutch Nuon and lost 1.5 billion EUR between 2010 and 2012. These bad investments, in combination with CCS programs, investments in production capacities and financial crisis led to deteriorated finances at the end of the phase, and cost-cut plans were implemented as well as disinvestments in some foreign markets.

Studies focusing more specifically on energy markets and Sweden show similarities to these general findings, although at a more fine-grained level. Högselius and Kaijser (2007) argue that the deregulation of the Swedish electricity market posed a threat for smaller municipal companies and generated considerable insecurity. The municipal companies previously had a guaranteed geographically regulated customer base, but competing for customers posed a challenge. Risks of not having a market for their produced electricity was a further concern, as was the insecurity regarding price development. The new electricity market would be more complex and pose insecurities regarding contract negotiations. Another strong reason to sell was the strained municipal economies at the time, as a sale would generate a substantial capital injection.

The electricity companies on the other hand could use this window of opportunity to more or less buy a customer base, and at the same time get closer to local markets. There was a fear that they would have difficulties in competing against municipal companies as they might be considered distant culturally. The large companies moved rather early, before deregulation took 
place, as a way to mobilize and strengthen their position. The shifting system boundaries that M\&A enabled, epitomized by Vattenfall's criticized European expansion (Högselius, 2009), was another reason as the large power-producing companies could become regional, national or even international (Högselius \& Kaijser, 2007). Ottosson (2011) and Bladh (2002) also argue that large industrial actors, like Stora and Uddeholm, which had been important power producers, chose to streamline the organization and sell parts that were not core business, meaning that the industry to a large extent exited the electricity market, leaving room for expansion of existing and new entrants.

DH was often sold simultaneously with the electricity company. In some cases, like in City of Stockholm where Finnish-owned Fortum bought Stockholm Energi, the sale of the DH was highly debated (Högselius \& Kaijser, 2007; Palm \& Magnusson, 2009), but in other cases the sale had a default character; it was assumed that the DH would be sold at the same time as the electricity. This is quite remarkable, but can probably be explained by the invisibility of the DH system and that the market potential was not correctly assessed by municipal actors, and that the risks of unfair pricing were not considered. It was also to a large extent a part of the liberal waves rolling in, that energy was to be handled by the market. To give an example of the vast amounts of capital involved, in the time period of a month in early 1996, acquisitions for 13 billion SEK of shares in Swedish power companies were done (Högselius \& Kaijser, 2007). It is fair to say that it is a matter of big business.

Bladh (2002) summarized that the electricity market became consolidated and concentrated between 1992 and 2002. Eight power-producing companies became four (then three after Sydkraft, now E.ON, bought Graninge in 2004) and the ownership became internationalized, as Finnish Fortum and German E.ON came in. Fifty-one municipalities also sold their electricity grid during the 1990 s and 100 sold their electricity trading. 
Andersson and Werner $(2005 ; 2001)$ concluded that a transformation in the DH sector from municipal utilities to municipal companies had started during the 1980s, as utilities delivered $33 \%$ of the heating in 1990, municipal companies $63 \%$ and Vattenfall and private companies the rest. In 2004, the municipal utilities were only $2.4 \%$ of the total delivered DH while municipal companies made up 58.4\% and the three large private or state-owned entities (Fortum, Sydkraft and Vattenfall) delivered 38.6\%. The "big three" from the electricity market had started to become dominant on the heating market as well.

\subsection{Effects of $M \& A$}

The liberalization and privatization of energy markets and the subsequent M\&As have fundamentally changed the playing field. As stated above, concentration and internationalization in ownership happened, but other events have occurred. Regulations concerning the re-configured markets have needed to be adjusted gradually, as Coutard (1999a) argued that deregulations requires considerable regulation as international oligopolies might be more damaging to the public compared to previous national or local industry-specific monopolies. Wissner (2014) concludes that for the German market, regulation of the DH sector is necessary regarding pricing. There are obstacles concerning regulating distribution grids, as there is a risk of costs being switched to production (waterbed effect), with lack of information concerning existing distribution system access.

The question of competition through third-party access has been present in the sector since the early 2000s, especially after Fortum bought the energy company in the city of Stockholm and with the sale of Uppsala Energi to Vattenfall, which in both cases led to rapidly increasing prices (Palm \& Magnusson, 2009; Rutherford, 2008). On two occasions, 2003-2005 and 20092011, a third-party access (TPA) to the DH systems in Sweden was subject to national investigations due to the customers' weak positions. The first investigation concluded that a mandatory TPA would not be beneficial for customers as risk of oligopoly was present as well 
as risk of system sub-optimization. The latter investigation came to another conclusion, although the requested mission from the Government this time was to investigate how, not if, a TPA should be introduced as a bill, which was the case in the earlier investigation (Hult, 2013). The general conclusion was that a vertical segregation of distribution, production and trade should be introduced in DH companies, price regulation in distribution should be introduced, and system owners should be obliged to permit access for another producer to distribute DH (SOU, 2011). The proposed bill faced criticism and it was only in 2014 that it was partially passed, meaning that access should be granted to new entrants under specific circumstances. It should be prime heating, the new plant should be previously unconnected to the system, and the system owner is obliged to present a reasonable proposal for agreement. The new deal should continue for ten years (“Fjärrvärmelagen”) (SFS 2008:263). The effects of the amendment are still to be evaluated.

Rutherford (2008) showed how the sale of the energy company in the city of Stockholm may not be an extreme case concerning splintering effects (Graham \& Marvin, 2001), although there are signs of a first stage of neoliberalism of space due to the selling off of the energy company, outsourcing of activities not considered core business in the water company, beginning of decreasing affordability of network services, an increasing distance between urban policy and infrastructure policy, and the non-intervention on the increasing prices from the municipal side, despite a 50\% financial interest. Magnusson (2013) saw changes on a regional level in the Stockholm region, as privatization of DH companies practically ended a rather successful 25year regional cooperation on energy. When run on non-market principles, the cooperation led to joint energy planning and subsequent interconnection of DH systems and construction of CHPs. When companies were run on profit-based principles, this open cooperation became impossible and has been reduced to purely financial arrangements. 


\section{Sociotechnical change}

This paper takes its departure in the sociotechnical literature concerning infrastructure and energy systems and the effects from institutional changes. The sociotechnical perspective was established by the work of Hughes (1983), identifying phases of development of Large Technical Systems (LTS) and the importance of non-technical aspects around the technical core, such as users, organizations, legislative artefacts and scientific components (Hughes, 1987). After several studies focusing on system development (La Porte, 1991; Mayntz \& Hughes, 1988; Summerton, 1992), a shift towards systems change was initiated by Summerton (1994), focusing on changing institutional contexts and reconfigurations of infrastructure management.

Summerton (1994) described reconfiguration of systems through reorganization from what were previously monopoly systems to new modes of management based on competition and open access. This liberalization and privatization that has occurred was a main focus of several studies in the late 1990s and early 2000s, focusing on the social and urban effects of changing logics of infrastructure provision and management (Graham \& Marvin, 2001; Guy et al, 1997; 1999). Liberalization leads to new strategies of niche marketing, social dumping and increased socio-spatial polarization. New market entrants and increased internationalization epitomize shifting networks and power in energy markets is likely to reveal social inequity, economic unevenness and environmental costs. New logics of network management focus on increasing profitability by concentration on most lucrative customers in "hot spots," through "cherry picking" of large commercial customers and other lucrative market segments. Cost and quality of service are new measurements as provision of energy no longer is seen as a functional service (Guy et al, 1997). The processes of M\&As has led to a consolidation of energy markets as actors are attempting to position themselves favorably within dominant and emerging markets (Graham \& Marvin, 2001). For this paper, cherry picking is a relevant concept considering the 
M\&A strategies seen in the Swedish DH market. While Guy et al. $(1997,1999)$ use the concept to explain the logics on a city level, focusing on specific areas and lucrative customers, I use it on a corporate level, explaining how large energy companies focused on acquiring lucrative DH systems in Sweden in order to strengthen their market position. Identifying large DH systems and companies with potential for profit was a strategy through cherry picking the most interesting ones.

The changes on the DH market are examples of sociotechnical change, and concepts from the sociotechnical transition literature (cf. Geels, 2002, 2004, Geels and Schot, 2007) including the multilevel perspective (MLP), are of relevance. Focus is on understanding technological transformations, and with specific attention to sustainability and low-carbon transitions. Sociotechnical systems, or configurations, that are established and developed are stable due to linkages between heterogeneous components and activities of social groups reproduce the linkages. The MLP emphasizes that transitions occur due to interplay between three levels, or scales: niche (micro), regime (meso) and landscape (makro). The regime is made out of rules and routines embedded in engineering practices, product characteristics, skills that are embedded in institutions and infrastructures (Rip \& Kemp, 1998), and with the additions of rules of relevant social groups, the sociotechnical regimes represent the dominant way of handling societal functions and are stable due to sunk investments and vested interest (Geels, 2002 , 2004). Niches are made out of incubators where innovation take place, before technologies reach the regime and become part of it. Change happens faster than in regimes, due to protection from market forces, and different selection criteria (Geels, 2002, 2004). The landscape level on the other hand provides the stability due to deep structural trends, such as oil prices, economic growth, environmental problems and political changes. The landscape is even harder to change than the regime (Geels, 2002). 
The relation between the three levels can be understood as a nested hierarchy, as radical novelties occur in the niche, but its success is dependent on development in the regime and landscape levels. Changes on the landscape level might put pressure on the regime, creating a "window of opportunity", generating possibilities for new technologies to become part of the regime (Geels, 2002).

Geels and Schot (2007) argue that different kinds of alignments at the three levels leads to different transition pathways, where "transformation" is of interest for this paper. Transformation occur when landscape pressure stimulate important actors to gradually modify the regime but niche innovations are not sufficiently developed. Examples used are societal pressures and protests demanding solutions, mobilizing pressure for stricter regulations. Bolton and Foxon (2013) argue that market liberalization, often seen as a background, landscape factor, is instead a key component of the sociotechnical regime as regulatory institutions actively stabilize the dominant sociotechnical pathway, maintaining techno-economic fixes and supply-side solutions. For this paper, the understanding of liberalization leading to transformation of the regime is of importance, as adjustments in order to adapt to new market rules were influencing regime actors. By using the terminology from the MLP, the ownership changes can be understood in relation to macro (landscape) events .

\section{Phases and trends}

The changes in the Swedish DH market, often as a reaction to the changes in the electricity market, can be divided into three phases: Pre-liberalization and early moves (through 1995); large ownership redistribution (1996-2005); and consolidation and large-scale disinvestments (2006 and on). Within these phases, a few larger trends emerge, which will be discussed below. 
Figure 1 shows the number of municipal DH company sales throughout the time period, showing that the time period 1990-2005 was the most hectic, although 1996-2000 was especially turbulent as 37 companies were sold.

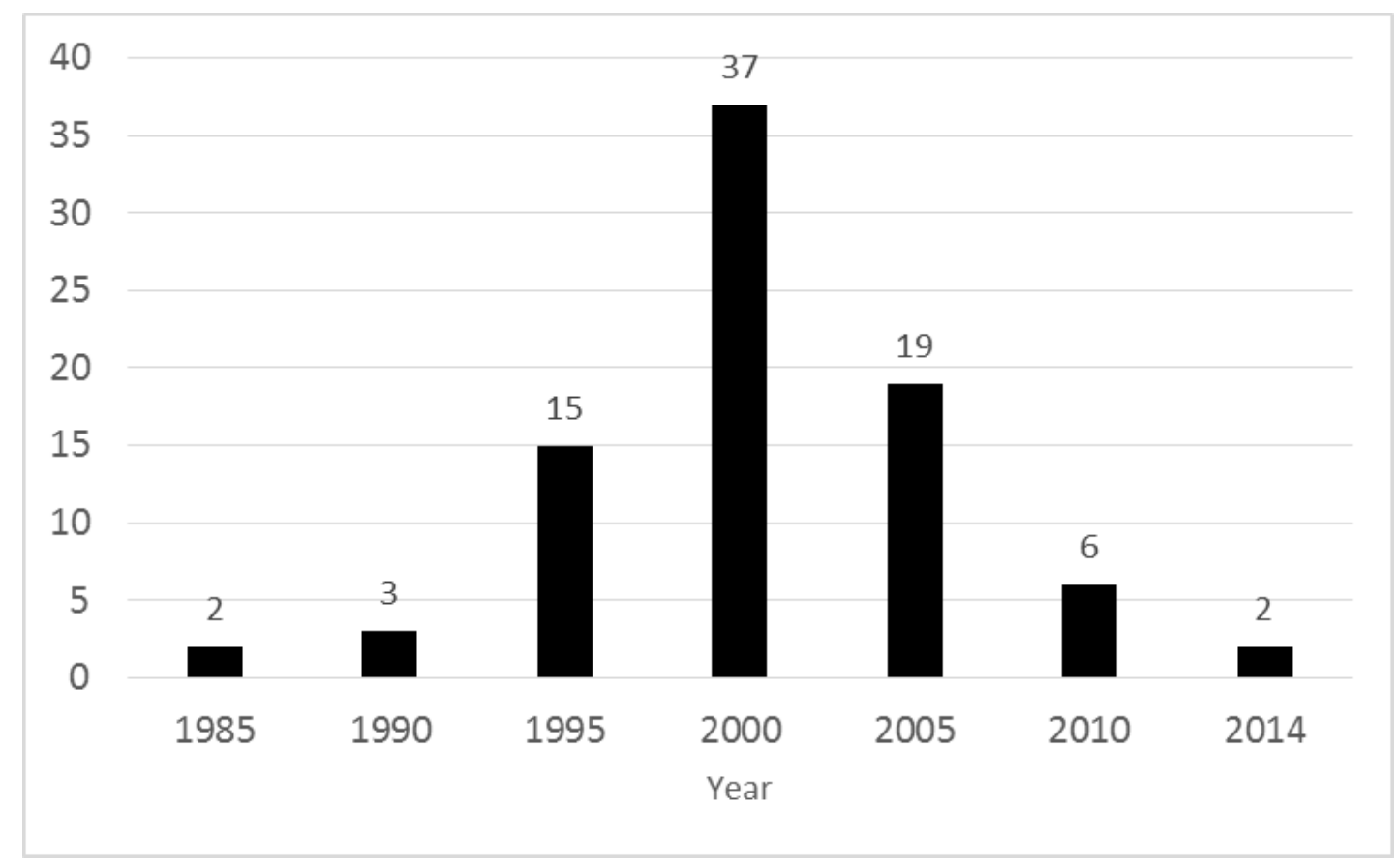

Figure 1. Amount of municipal DH company sales 1985-2014 in five-year intervals.

\subsection{Pre-liberalization and early moves (through 1995)}

The liberalization of the energy market in Sweden was discussed and politically debated for several years before it was realized in 1996. The inspiration came from the processes taking place some years previously in Norway and Great Britain and there were some strong proponents in the ministry of economy (Högselius \& Kaijser, 2007). The landscape trends pointed towards liberalization internationally, but also nationally through privatization and reor deregulation of state monopolies during the late 1980s and '90s: telephony, domestic flights, postal services and financial markets, to mention a few. The M\&As on the Swedish energy market started already in the late 1980s, but the corporatization of state-owned Vattenfall in 1992 was arguably the first step towards the "new era" of ownership (Bladh, 2002; Högselius \& Kaijser, 2007). 
In total, $20 \mathrm{DH}$ companies were sold during this period, although 15 of them took place between 1990 and 1995. A major early acquisition took place in 1991, when Sydkraft bought Malmö Energi, the energy company in the third largest city in Sweden. This was a typical case of vertical integration, as Malmö Energi had been a customer to the producing unit of Sydkraft. This was also the argument in several other deals at the time (Högselius \& Kaijser, 2007). It can be argued that in the early 1990s, the landscape ideological trends pointed towards liberalization sooner or later, and Bladh (2002) argues that it is of strategic importance to obtain a stable customer base. Although small consumers are seldom economically advantageous, nevertheless it generates a stable revenue stream. As presented by Haleblian et al. (2009), making moves early in acquisition waves is important, and the years around 1995 showed a race between a handful of actors in order to strengthen their position on the market (Högselius \& Kaijser, 2007).

There were several interesting units on the market during this time period. As mentioned above, municipalities felt insecurity about the new market structure or had financial reasons, and industries were streamlining their organizations; the incumbent regime actors were adjusting to new prerequisites. It was a window of opportunity to strategically work towards the future, but to strengthen the position for those aiming to thrive on the new market, it can arguably be framed as a window of necessity to open their wallets and spend. As mentioned, the focus was electricity, but DH businesses later proved to be lucrative, especially in the large systems.

\subsection{The large ownership redistribution (1996-2005)}

This time period was the most active concerning ownership changes as a total of 56 municipalities sold their DH companies during these years. One trend was diversification in ownership, changing from over $95 \%$ municipal ownership in the late 1980s to a structure including e.g. privately owned businesses, jointly owned by more than one municipality, jointly owned by private interests and municipalities, state-owned and cooperatives. DH systems are 
unique in their character as they develop individually, in specific municipal contexts. For example, in the southern part of the Stockholm region, there is a strong history of cooperation between municipalities and it was a rather logical move to develop the DH systems in jointly owned companies, while Malmö and Lund in southern Sweden on the other hand have a historic rivalry, meaning that a joint company seems rather far off. The diversification in ownership further strengthens these unique characteristics.

The time period trailed the electricity market development, with three big players standing out: E.ON, Fortum and Vattenfall. These strengthened their position considerably through acquisitions, meaning that they owned DH systems in 48, 21 and 28 municipalities respectively in 2005, a total of 89 municipalities, almost a third of the total. That was $41 \%$ of the total production; it is fair to say that the "big three" had a strong market position between them. E.ON continued their expansion through acquisition of several medium-sized systems all over Sweden, Fortum in mid-Sweden, often in old industrial municipalities and Vattenfall followed in a similar matter. Strategies concerning acquisitions are not as evident, except first focusing on hot spots through cherry picking lucrative systems. As these became rarer, systems in smaller municipalities were bought. It was more a question of expanding through acquisitions rather than production capacity, much like Kungl's (2015) findings in Germany.

At the end of May 2014, 51\% of the municipalities had owners that were purely municipal, i.e., one municipality owning the whole DH company alone, $20 \%$ of the municipalities had private owners and 4\% were state-owned DH systems, see Table 1.

Table 1. Forms of ownership Swedish district heating companies

\begin{tabular}{|c|c|c|c|}
\hline Ownership & Municipalities & Companies & $\begin{array}{r}\text { Delivered heat (GWh) } \\
2013\end{array}$ \\
\hline Municipal & 148 & 128 & 32900 \\
\hline Private & 58 & 10 & 7319 \\
\hline
\end{tabular}




\begin{tabular}{|c|c|c|c|}
\hline Jointly municipal & 20 & 10 & 5141 \\
\hline Jointly municipal and state-owned* & 16 & 6 & 9690 \\
\hline Jointly municipal and private & 13 & 10 & 1079 \\
\hline State-owned & 12 & 2 & 3398 \\
\hline Other & 9 & 6 & 460 \\
\hline Cooperative & 7 & 7 & 212 \\
\hline No district heating & 7 & - & - \\
\hline \multirow[t]{2}{*}{ Total } & 290 & 179 & 60226 \\
\hline & pal or & this & \\
\hline
\end{tabular}

The geographical distribution of ownership can be seen in Figure 2. The gray areas represent those that still have municipal ownership. In northern Sweden the municipalities are owners to a large extent, while there is a large share of private owners in mid-western Sweden. The Stockholm region and Skåne are highlighted due to the high share of private owners and high variety of ownership. 


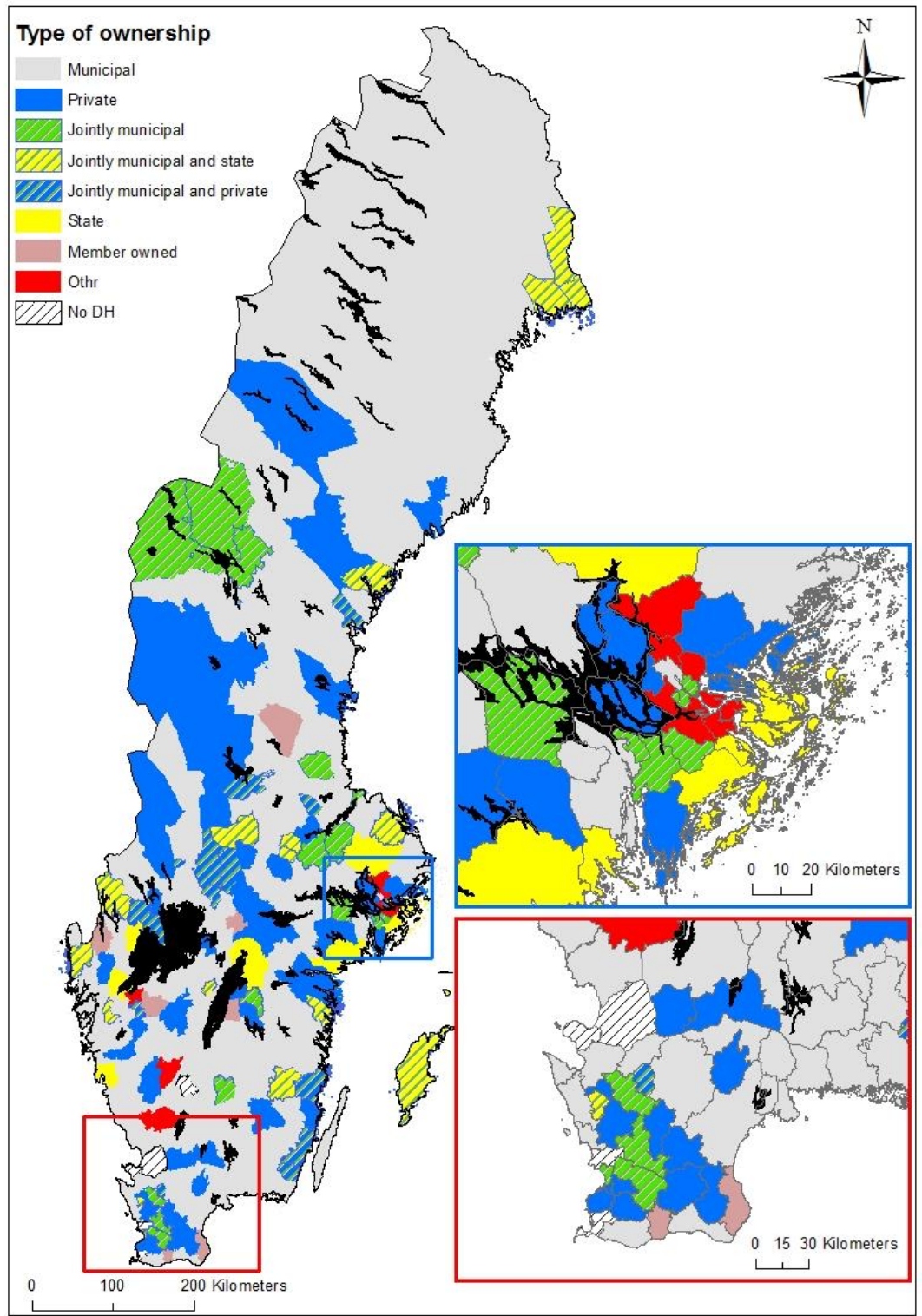

Figure 2. Geographical distribution of ownership forms. Top (blue) rectangle represents the Stockholm region and the bottom (red) Skåne.

Another pattern emerges when studying independent municipal ownership, see Table 2. In 125 municipalities the municipality itself owns the DH business, and in 43 more, they have economic interest. In total, in 196 municipalities there is municipal ownership, but the control over municipality itself is less than compared to the early 1990s as there were only a few municipalities with DH that did not own their DH company. 
industrial users. The situation on the Swedish DH market is not cherry picking of specific customers as much as lucrative city regions. There is a reason that the Stockholm region is subject to substantial amounts of M\&As, due to the dense building structure, well-developed physical DH systems and high population.

Municipally owned Stockholm Energi was an early example of privatization. The first steps were taken in the early 1990 s through vertical integration of production and distribution of the electricity, making them more interesting for acquisition, and the initial plan was to sell a major part of the company (15-20\%) and allow public trade for approx. $30 \%$ while still maintaining $51 \%$ municipal ownership. The initial offers from British bidders fell apart, but these early plans later became realized when Fortum (then IVO) bought $50 \%$ of the company, although not the DH business in the first step, in 1998 and the rest in 2002. The city maintained 50\% economic interest after 2002 and 9\% ownership in the DH business (Högselius \& Kaijser, 2007).

Fortum started to make moves in Sweden and the Stockholm region, buying three neighboring systems in the latter around 2000. At peak ownership around 2005, they owned DH systems in 21 municipalities. The fact that the city of Stockholm kept the economic interest in the business proved lucrative; in 2007-2014 the annual yield to the owners has been 400 MSEK (approx. 40 million EUR), of which the city of Stockholm has received 50\% (Fortum, 2007, 2008, 2009, 2010, 2011, 2012, 2013, 2014). Questions can be raised regarding yields generated by customers in neighboring municipalities being paid, as in the case of Fortum, to the city of Stockholm or shareholders (Palm \& Magnusson, 2009).

Other major municipalities in Sweden, like Malmö, Uppsala, Örebro and Norrköping, have all been sold to private (Sydkraft/E.ON) or state-owned (Vattenfall) actors. These all have old and well-established systems and are thus important markets. Most of the larger municipalities in 
Sweden have bought systems in neighboring municipalities, or expanded into them. That is the case in Gothenburg, Linköping, Västerås, Helsingborg and Lund; they have become regional energy companies. It does not seem to be enough to "just" own systems in one's own municipality.

As seen in Figure 2, diverse ownership occurs in areas outside of the major urban regions, for example north of Örebro in central-south Sweden. These are municipalities that are not seen as hot spots, but they have become hot spots due to the streamlining of industries. The industries invested in electricity production more than 100 years ago and have been major energy producers, and have thus often started DH systems. When selling off the energy business, the DH systems came into the hands of private actors.

Another strategy has been to buy neighboring systems, for example Rindi in Skåne or E.ON's former ownership in central and northern Sweden. This must be seen as a case of strategically trying to generate cash flow while generating synergy effects of geographically close units.

Waves of M\&A might be followed by counter-movements and one that has taken place is remunicipalisation of DH systems. A total of 21 municipalities have bought back a DH system, and in the majority of cases it has been a system that was started together with another partner, such as Vattenfall in the north, the DH system establishment probably being due to already established relationships through hydro power plants. Four municipalities have bought back systems they started themselves, three have bought companies started by others and in the rest of the cases these were jointly established. The reasons for remunicipalisation are to a large extent to obtain control over an important system and price control (Energinytt, 2009).

Internationally, there have been some cases of remunicipalisation, such as the water business in Grenoble and energy movements in Germany. The reasons have been belief in greater efficiency of public sector provision and more control over the measures in order to fulfil public 
policy objectives (Hall, Lobina, \& Terhorst, 2013). Becker et al (2012) (see also Moss et al, 2014) argue that the highly visible debates regarding a possible remunicipalisation of the energy company in Berlin (Vattenfall being the owner) is not only a question of ideology, but rather a concern of sustainability, participatory democracy, social justice and citizen ownership. After the "Energiwende" a number of smaller municipalities bought back the energy company, arguments often being local control over energy production and local revenue streams, but each case has been unique.

The mapping of the Swedish ownership changes has shown a historical pattern that puts the traditional assumption of municipal establishment into some new light. A common narrative regarding the DH development is a municipal story, starting in 1948 in Karlstad. In most municipalities that is also true, the reasons being for example the strong municipalities, a history in energy production and distribution, planning monopolies and important initial markets in public housing. However, in 80 municipalities there are DH companies that have not been started solely by a municipality. This is a development not covered in the literature, as most studies have focused on establishment of municipal systems with the municipality being the sole owner ( Kaijser \& Summerton, 1983; Summerton, 1992).

In 48 municipalities there was another company that established the system. Rindi Energi for example established six systems around 2000, the later bankrupt Energi System established four while Vattenfall and Skellefteå Kraft each established three. Thus not all have been private or state-owned. Farmers have also established five systems. In some occasions, DH systems have expanded into neighboring municipalities, such as in Nacka and Danderyd in the Stockholm region (Magnusson, 2013). 
29 DH systems were established jointly between the municipality and another company, Vattenfall being the partner in 17 cases, the majority in northern Sweden, and established before 1990 .

Systems started after the liberalization have to a large extent been established by parties other than the municipality itself. Systems were established in 71 municipalities, with 31 of these by private or state-actors, 26 by the municipality itself, five by other municipalities, five by jointly private-municipal owned companies, four by jointly owned municipal companies and in one case another municipal company has expanded into the municipality. It can be argued that this change in establishment structure has to do with the fact that the municipalities do not have the same economic resources as in the 1960s and 70 s, and that private companies instead do, as long as they run energy companies in other municipalities.

\subsection{Consolidation and large-scale disinvestments (2006-).}

The last phase is characterized by stabilized and consolidated ownership structures, with only eight municipalities selling off their DH business. Movements in the markets have not ended, however. As Kungl (2015) explained from the German perspective, several of the big players had strained finances in the late 2000s and needed to free up capital. This started a wave of large scale disinvestments in Sweden.

Vattenfall was first to initiate sales, when in 2007 they sold DH systems in ten municipalities, none of them of major size (seven to Finnish Neova). This was a case of vertical integration for Neova, as they are a major producer of wood fuel. The strategy of Vattenfall was to focus on the core business, to sell parts that are not in line with the company's future strategic orientation or do not live up to the demands for yield (Vattenfall, 2007; 2008; 2009). They continued this process, selling three more systems in 2009 (e.g. Luleå and Piteå in which they were part owners), to end up with DH systems in ten municipalities in 2014. 
Fortum was next in line to start a process of large-scale disposal. Between 2007 and 2011, they sold DH companies in 15 municipalities, the first in southern Sweden. A few of them, Laxå and Arvika, were sold to the respective municipality, but the rest were sold to Maquire Power \& Infrastructure Fund in 2010, starting a company under the name Värmevärden. The logics behind Fortum's move was to focus on long-term investments in the Stockholm region, especially in CHPs (Fortum, 2010).

The last of the "big three" to carry out this process was E.ON, which sold 26 systems in 17 municipalities in early 2014, all of them smaller systems (a total of $500 \mathrm{GWh}$ ). The reason for the sales was that they wanted to free resources for investments in "innovations concerning district heating and at the same time increase our focus on quality and service" (E.ON, 2014, p. 8 , author's translation).
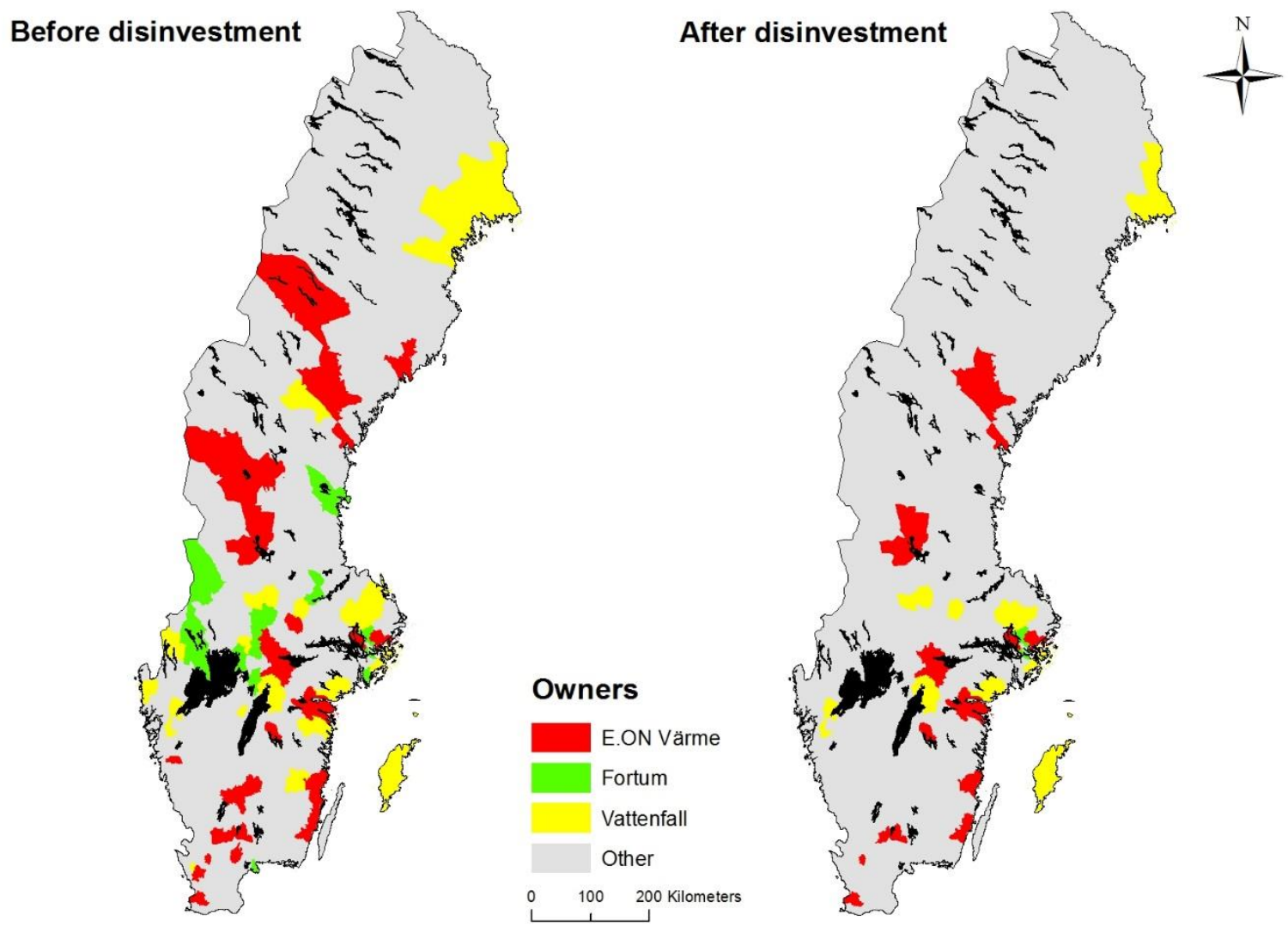

Figure 3. Geographical distribution of DH-businesses for E.ON, Fortum and Vattenfall before and after large-scale disinvestment. 
As seen in Figure 3, there has been a concentration in ownership to strategic places. Vattenfall has left large parts of northern Sweden, E.ON has concentrated ownership geographically to a few places in the north and Fortum is now only present in the Stockholm region.

During the large-scale disinvestment there were rather few cases of remunicipalisation, Laxå and Arvika being exceptions. There was some interest during E.ON's sales, e.g. Mönsterås in southern Sweden, but E.ON stated that they wanted to sell the systems as a bundle (Barometern, 2014). Fortum sold the two previously mentioned systems to municipalities, but sold the rest in a bundle, as did Vattenfall. This was probably an efficient deal rather than negotiating with several different partners, but it also left out potential buyers, such as municipalities.

The reasoning behind the disinvestment needs to be seen in light of Kungl's (2015) findings of crisis and reorientation. The findings of Hableblian et al. (2009) regarding acquisition experience and managerial self-interest seem relevant, as the business culture in these companies pointed towards mergers in order to maximize economic performance and lucrative pairings, but it is possible that a case of speed-blindness developed, and the aftermath showed economic crises. It is not far-reached to assume that the systems sold were not the most lucrative, which might have been an additional reason to sell, thus another case of cherry picking. It does however illustrate how little say customers have, as they will once again have a new DH supplier without any input from them. It can also be noted, as was stated by Haleblian et al. (2009), that a history of M\&A seems to lead to further acquisitions and in these municipalities, the "big three" have seldom started the DH systems, with a few exceptions, and thus have no emotional ties to the systems while political debates are nonexistent. In most of the cases, the reports that the sales were upcoming have been limited so these are deals that have been done out of sight and mind of the customers. 
Ownership structure is today quite different from the situation at the start of the phase, see

Table 3. Today E.ON is still the company owning systems in most municipalities, but just like Vattenfall and Fortum, they have decreased their number of municipalities considerably. They are not the "big three" anymore concerning number of systems, but considering delivered heat they are still the largest. Solør Bioenergi is the owner in several municipalities, as well as owner of Rindi Energi, meaning that they have interest in 24 municipalities.

Table 3. Largest owners on the Swedish district heating market.

\begin{tabular}{|c|c|c|c|c|}
\hline Company & $\begin{array}{r}\text { Municipalities } \\
2014\end{array}$ & $\begin{array}{r}\text { Delivered } \\
\text { heat } 2013^{1} \\
(G W h)\end{array}$ & $\begin{array}{r}\text { Municipalities } \\
2005\end{array}$ & $\begin{array}{r}\text { Delivered heat } \\
2005 \text { (GWh) }\end{array}$ \\
\hline E.ON Värme² & 22 & 4,900 & 41 & 7,700 \\
\hline Solør Bioenergi & 13 & 500 & - & - \\
\hline Rindi Energi AB & 11 & 400 & 13 & 300 \\
\hline Vattenfall & 10 & 2,700 & $28^{3}$ & 4,000 \\
\hline Värmevärden AB & 10 & 900 & - & - \\
\hline Neova AB & 8 & 200 & - & - \\
\hline Skellefteå Kraft AB & 7 & 600 & 7 & 400 \\
\hline $\begin{array}{l}\text { Fortum Värme co-owned } \\
\text { with city of Stockholm }\end{array}$ & 6 & 8,200 & 21 & 8,500 \\
\hline Söderenergi & 5 & 2,500 & 5 & 1,700 \\
\hline Tekniska Verken Linköping & 4 & 1,600 & 4 & 1,200 \\
\hline Mälarenergi $A B$ & 4 & 1,500 & 2 & 1,500 \\
\hline Kraftringen & 4 & 900 & 4 & 1,000 \\
\hline
\end{tabular}

\footnotetext{
${ }^{1} 2013$ was the last complete year from which to present statistics, but between year-end of 2013 and June 2014, additional ownership changes have occurred. These statistics still give a reasonable guidance regarding the amount. These numbers also need to be understood in relation to number of grade-days, i.e., the year's climate.

${ }^{2}$ Sydkraft changed its name to E.ON during 2005.

${ }^{3}$ In these Västerbergslagens Energi is not included.
} 
The geographical distribution in ownership can be seen in Figure 4, showing graduated colors based on owners. E.ON is the biggest owner (considering municipalities) and has to a large extent concentrated its ownership geographically to the Stockholm region, a few larger cities (Örebro, Norrköping) and to the south, with some other smaller, from the perspective of delivered heat, places. 


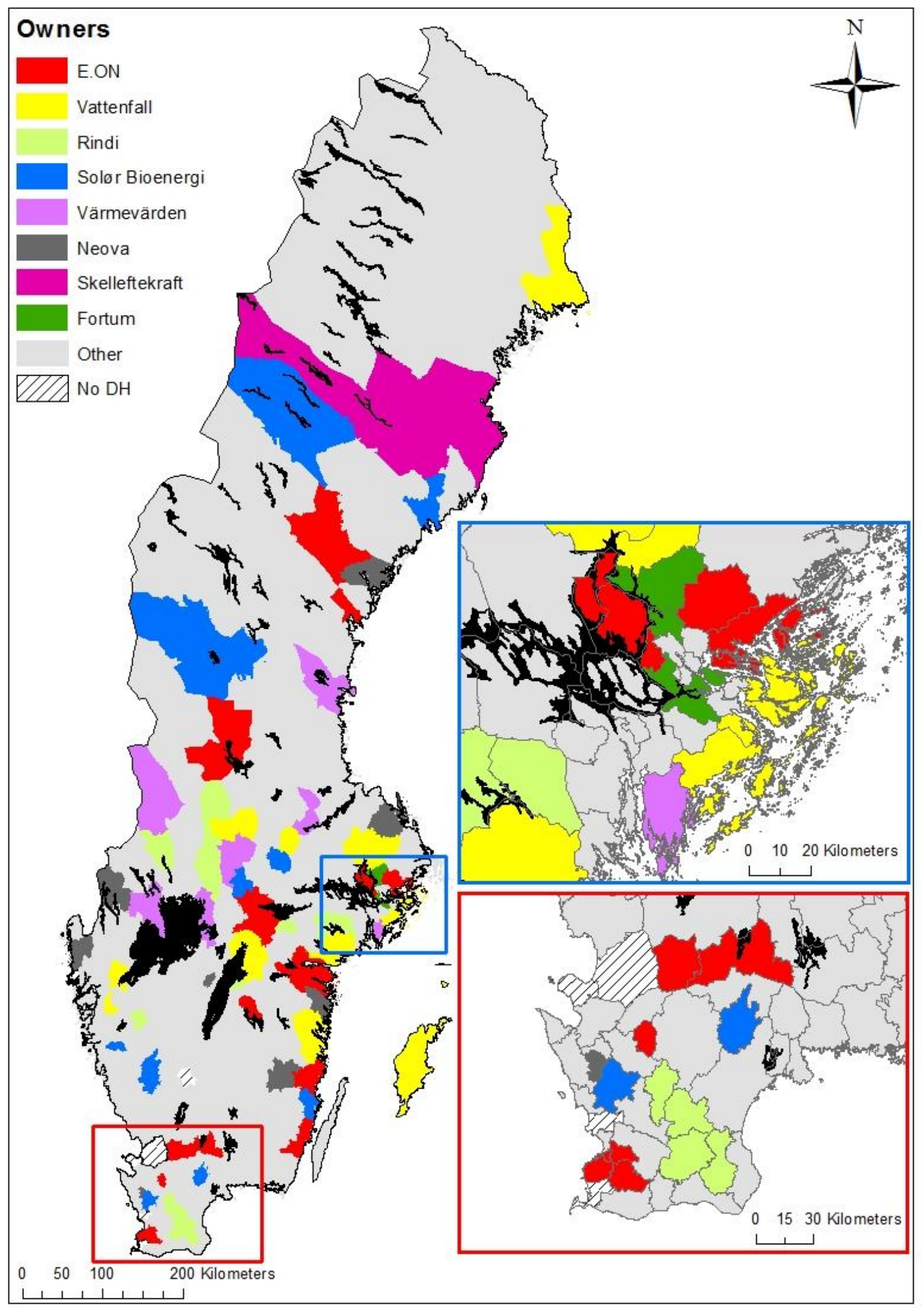

Figure 4. Geographical distribution of largest owners. The top rectangle (blue) shows the Stockholm region and the bottom (red) shows Skåne. 
A final mapping has been done considering political majority in municipalities at the time of sale. The result shows that a reasonable assumption that liberal/bourgeois ("center-right") parties would favor privatization is not an evident pattern at all. Out of 83 municipalities that sold their DH company, 26 of them had a conservative majority running the municipal assembly, 45 had a socialist majority (social democrats and Left party or Green party), and in the 12 remaining, the majority was a coalition of both right-wing and left-wing parties. In other words, the political colors do not seem to be the dominant determinant.

\section{Concluding discussion}

The paper has shown a changed ownership structure on the Swedish district heating market in response to liberalization of the national electricity market. A wave of acquisitions primarily focusing on electricity production and distribution took place, as a way to strategically prepare for the competitive market structure. DH has often been developed simultaneously with electricity in municipal utilities and later companies, and DH was then sold at the same time as the electricity system components.

Liberalization then was a window of opportunity, as a way to strengthen market position through acquisitions at the same time as industries streamlined organizations and sold non-core business like energy businesses and municipalities saw risks in the new institutional settings. It also became a window of necessity for the market players with ambitions to survive and thrive on the market, to move early through acquisitions as a way to build a steady base of revenue streams.

A number of trends can be identified, and an especially clear one has been a diversification in ownership, from municipal ownership to a diverse picture of national and international owners. The municipalities are still owners in the majority of municipalities (51\% as sole owners), but in several hot spots, private or state-owned companies are now in control over the heating 
supply. A general conclusion is that municipalities to some extent have abandoned the energy market and left the control to others. It was also shown that the political hues of the governing municipal assembly did not matter regarding sales; energy companies were sold by social democrats, conservative parties and coalitions.

There are counter-movements through trends of remunicipalisation of DH companies, in order to regain some of the control. This is arguably a response to the increased prices taking place, but these trends would need closer examination.

The wave of acquisitions of municipal energy companies ended around 2005, but it was just a breather before the "big three" of E.ON, Fortum and Vattenfall decided to initiate programs of large-scale disinvestment. Between 2007 and 2014, these companies sold DH systems in 52 municipalities, as parts of strategies to free up capital, streamline organizations, and prepare for further investments. This is in line with Kungl's (2015) findings that at least E.ON and Vattenfall were in need of capital infusion after several less successful European deals. However, it can also be seen as a cherry-picking strategy, to get rid of less lucrative systems, and it does show a trend of less connection to the individual systems; they did not start them and thus have no emotional hindrances selling them. The customers have no control over this development. Acquisitions of systems are large investments and there are always risks of the owners wanting to get their investment back over a rather short time period, leaving risks for further price increases.

In parallel with the market transformation due to liberalization, Di Luca and Ericsson (2014) show how another transition pathway, de/re-alignment, when major landscape pressures destabilize the regime and initial co-existence of niche-innovations leads to formation of a new regime around one of them (Geels and Schot, 2007), took place. The transition towards lowcarbon DH started in the late 1980`s and took off during the 1990`s as biomass replaced oil as 
fuel to a large extent, due to policies such as oil reduction plans, carbon tax and the local climate change investment program (Werner, 2007). The strong connections between electricity and $\mathrm{DH}$ is evident, as these separate regimes must be understood in relation to each other in at least two cases: as a part of the same companies before liberalization and in relation to recent years of CHP development (Magnusson, 2012). Landscape pressure, and arguably regime pressure due to interest from several large companies and policy makers, for liberalization of the electricity market forced transformation of DH regime, at first without any clear understanding of the implications, but with price increases in the early 2000s. Possibilities to build capital in DH businesses under market pricing generated the window of opportunity for these massive investments, thanks to the commercialization of the DH market.

Sweden now has several different ownership forms, and as the DH potential in Europe has been identified in Europe (EC, 2016; Conolly et al, 2014), Sweden might be a role model for developing systems. A "best practice" is precarious to identify, as e.g. heat density, geography, existing competing infrastructure matter, although a few points can be made. As several authors have stated (cf. Coutard, 1999, Wissner, 2014) liberalization requires adjustments and as DH unavoidably makes natural monopolies the lock-in effects leads to weak position for customers. Factors like company size, requirement for yield and fuel use matter for price levels (Andersson \& Werner, 2003), although Åberg et al (2014) argue that municipal companies to a larger extent give priority to political goals rather than economical and that they tend to a larger extent use cost-based pricing as pricing strategy. It can in any case be argued that cooperation among DH companies, for example municipal joint ownership and interconnections of systems, have proved fruitful for economic and environmental concerns as risks are dispersed, load factor and economic mix increase and fossil fuel use decrease (Magnusson, 2013). 
Further studies and critical examinations of the above-stated trends are welcomed, as the DH market is an important market for customers, involved actors and for GHG emission reduction.

\section{Acknowledgments}

The author would like to thank two anonymous reviewers for valuable comments for improvements for the paper. Further thanks to the research group Technology, Everyday Life, Society (TEVS) for comments on an early draft, as well as thanks to Mats Bladh for comments. This work was supported by The Swedish Research Council Formas through JPI - Climate Joint Call for Transnational Collaborative Research Projects, Societal Transformation in the Face of Climate Change in the project ""Mobilizing grassroots capacities for sustainable energy transitions: path improvement or path change?".

\section{References}

Andersson, S., \& Werner, S. E. (2001). Svensk fjärrvärme : ägare, priser och lönsamhet. Göteborg: Energy Systems Technology Division, Chalmers University of Technology.

Andersson, Sofie \& Werner, Sven (2003). Fjärrvärme i Sverige 2001: En analys av ägande, jämställdhet, priser och lönsamhet i svenska fjärrvärmeföretag med vissa internationella utblickar. Report. Västerås: FVB.

Andersson, S., \& Werner, S. (2005). Fjärrvärme i Sverige 2003 - En analys av råvarukostnader, ägande, jämställdhet, priser och lönsamhet $i$ svenska fjärrvärmeföretag. Göteborg: Energy Systems Technology Division, Chalmers University of Technology.

Becker, S., Gailing, L., \& Naumann, M. (2012). Neue Energielandschaften-neue Akteurslandschaften: eine Bestandsaufnahme im Land Brandenburg: RosaLuxemburg-Stiftung. 
Bladh, M. (2002). Kraftbolagen, kommunerna och elavregleringen: ägarförändringar $i$ elbranschen 1991-2002. Tema T Working paper 251, Linköping University.

Bolton, R., \& Foxon, T. J. (2013). Urban infrastructure dynamics: market regulation and the shaping of district energy in UK cities. Environ. Plan. A, 45(9), 2194-2211.

Cicchetti, C. J., Dubin, J. A., \& Long, C. M. (2004). The California electricity crisis: What, why, and what's next. Boston, MA: Kluwer Academic Publishers.

Connolly, D., Lund, H., Mathiesen, B. V., Werner, S., Möller, B., Persson, U., Boermans, T., Trier, D., Østergaard, P.A., \& Nielsen, S. (2014). Heat Roadmap Europe: Combining district heating with heat savings to decarbonise the EU energy system. Energy Policy, 65, 475-489.

Coutard, O. (1999). Introduction: the evolving forms of governance of large technical systems. In O. Coutard (Ed.), The Governance of Large Technical Systems (pp. 1-16). London: Routledge.

Di Lucia, L., \& Ericsson, K. (2014). Low-carbon district heating in Sweden-Examining a successful energy transition. Energy Research \& Social Science, 4, 10-20.

EC (2004). Cogeneration directive. Directive 2004/8/EC.

EC (2012). Energy efficiency directive. Directive 2012/27/EU.

EC (2016). Commission Communication on an EU strategy for heating and cooling.

Energinytt (2009). Kommunen ensam ägare i Pite Energi. Published 2009-04-27. Internet source: http://energinytt.se/ovriga-artiklar/kommunen-ensam-agare-piteenergi/. Retrieved 2015-06-04

E.ON. (2014). E.ON - Årsredovisning 2014. [Annual report].

Fortum. (2007). Inblick 2007 - Fortum Värme samägt med Stockholms stad. [Annual report]. 
Fortum. (2008). Inblick 2008 - Fortum Värme samägt med Stockholms stad. [Annual report].

Fortum. (2009). Inblick 2009 - Fortum Värme samägt med Stockholms stad. [Annual report].

Fortum. (2010). Inblick 2010 - Fortum Värme samägt med Stockholms stad. [Annual report].

Fortum. (2011). Inblick 2011 - Fortum Värme samägt med Stockholms stad. [Annual report].

Fortum. (2012). Inblick 2012 - Fortum Värme samägt med Stockholms stad. [Annual report].

Fortum. (2013). Inblick 2013 - Fortum Värme samägt med Stockholms stad. [Annual report].

Fortum. (2014). Inblick 2014 - Fortum Värme samägt med Stockholms stad. [Annual report].

Geels, F. W. (2002). Technological transitions as evolutionary reconfiguration processes: A multi-level perspective and a case-study. Research Policy 31 (8/9): 1257-1274.

Geels, F. W. (2004). "From sectoral systems of innovation to socio-technical systems: Insights about dynamics and change from sociology and institutional theory." Research policy 33(6), 897-920.

Geels, F. W. \& Schot, J. (2007). "Typology of sociotechnical transition pathways." Research policy 36(3), 399-417.

Government bill 2008/09:162. En sammanhållen klimat- och energipolitik. [Energy and climate proposition].

Graham, S., \& Marvin, S. (2001). Splintering urbanism: networked infrastuctures, technological mobilities and the urban condition. London: Routledge.

Guy, Simon, Graham Stephen \& Marvin Simon (1997). Splintering networks: Cities and technical networks in 1990s Britain. Urban Studies 34 (2): 191-216.

Guy, Simon, Graham, Stephen \& Marvin, Simon (1999). Splintering Networks: the Social, Spatial and Environmental Implications of the Privatisation and Liberalisation of 
Utilities in Britan. In The Governance of Large Technical Systems, Olivier Coutard (ed.), 149-169. London: Routledge.

Haleblian, J., Devers, C. E., McNamara, G., Carpenter, M. A., \& Davison, R. B. (2009). Taking stock of what we know about mergers and acquisitions: A review and research agenda. Journal of Management, 35(3), 469-502.

Hall, D., Lobina, E., \& Terhorst, P. (2013). Re-municipalisation in the early twenty-first century: water in France and energy in Germany. International Review of Applied Economics, 27(2), 193-214.

Hawkey, D., Webb, J., \& Winskel, M. (2013). Organisation and governance of urban energy systems: district heating and cooling in the UK. Journal of Cleaner Production, 50, $22-31$

Hult, D. (2013). Det reglerade fjärrvärmeavtalet: Etapp två. Fjärrsyn Report 2012:13. Stockholm: Svensk fjärrvärme.

Hughes, T. P. (1983). Networks of power: Electrification in Western society, 1880-1930. Baltimore, MD: Johns Hopkins Univ.Press.

Hughes, T. P. (1987). The evolution of large technological systems. The social construction of technological systems: New directions in the sociology and history of technology, $51-82$

Högselius, P. (2009). The internationalization of the European electricity industry: The case of Vattenfall. Utilities Policy, 17(3), 258-266.

Högselius, P., \& Kaijser, A. (2007). När folkhemselen blev internationell : elavregleringen i historiskt perspektiv (1. uppl. ed.). Stockholm: SNS förlag. 
Kaijser, A., \& Summerton, J. (1983). Att välja värmesystem : Motalas framtida värmeförsörjning ur organisatorisk synvinkel. Linköping,.

Kungl, G. (2015). Stewards or sticklers for change? Incumbent energy providers and the politics of the German energy transition. Energy Research \& Social Science, 8, 13-23.

La Porte, T. R. (Ed.) (1991). Social responses to large technical systems: control or anticipation. Dordrecht: Kluwer Academic Publishers.

Lee, W.-W. (2004). US lessons for energy industry restructuring: based on natural gas and California electricity incidences. Energy Policy, 32(2), 237-259.

Magnusson, D. (2013). District Heating in a Liberalized Energy Market: A New Order? Planning and Development in the Stockholm Region, 1978-2012. (Ph.D.), Linköping University, The Department of Thematic Studies, Linköping.

Magnusson, D. (2015). Ägarförändringar på den svenska fjärrvärmemarknaden: en översikt över förvärv och avyttringar 1990-2014. Tema T Working paper 353. Linköping University.

Mayntz, R., \& Hughes, T. P. (1988). The development of large technical systems (Vol. 2). Frankfurt am Main: Campus Verlag.

Midttun, A. (1995). Understanding Change: electricity liberalization policies in Norway and Sweden. In: Kaijser, A \& Hedin, M. Nordic energy systems. Historical perspectives and current issues. Canton, MA: Science History Publications USA, pp. 141-168.

Monstadt, J. (2007). Urban governance and the transition of energy systems: Institutional change and shifting energy and climate policies in Berlin. International Journal of Urban and Regional Research, 31(2), 326-343. 
Moss, T. (2008). 'Cold spots' of urban infrastructure:'Shrinking’processes in eastern Germany and the modern infrastructural ideal. International Journal of Urban and Regional Research, 32(2), 436-451.

Moss, T., Becker, S., \& Naumann, M. (2014). Whose energy transition is it, anyway? Organisation and ownership of the Energiewende in villages, cities and regions. Local Environment(ahead-of-print), 1-17.

Naumann, M., \& Bernt, M. (2009). When the tap stays dry: water networks in eastern Germany. Local Environment, 14(5), 461-471.

Newbery, D. M. G. (1999). Privatization, restructuring, and regulation of network utilities. Cambridge, MA: MIT Press.

Ottosson, M. (2011). Opposition and Adjustment to Industrial 'Greening': The Swedish Forest Industry’s (Re) Actions regarding Energy Transition-1989-2009. (Ph.D.), Linköping University, The Department of Thematic Studies, Linköping.

Palm, J., \& Magnusson, D. (2009). Medias rapportering om fjärrvärme: framställning och budskap nationellt och lokalt. Fjärrsyn Report 2009:32. Stockholm: Svensk fjärrvärme.

Rip, A.,\& Kemp, R. (1998). Technological change. In: Rayner, S., Malone, E.L. (Eds), Human Choice and Climate Change, Vol. 2. Battelle Press, Columbus, OH, pp. 327399.

Rutherford, J. (2008). Unbundling Stockholm: The networks, planning and social welfare nexus beyond the unitary city. Geoforum, 39(6), 1871-1883.

Sataøen, H. L., Brekke, O. A., Batel, S., \& Albrecht, M. (2015). Towards a sustainable grid development regime? A comparison of British, Norwegian, and Swedish grid development. Energy Research \& Social Science. 
Silveira, S. \& Johnson, F.X. (2016). Navigating the transition to sustainable bioenergy in Sweden and Brazil: Lessons learned in a European and International context. Energy Research \& Social Science, 13, 180-193. DOI: http://dx.doi.org.e.bibl.liu.se/10.1016/j.erss.2015.12.021

Sioshansi, F. P. (2006). Electricity market reform: What has the experience taught us thus far? Utilities Policy, 14(2), 63-75.

Sioshansi, F. P. (2008). Competitive electricity markets: questions remain about design, implementation, performance. The Electricity Journal, 21(2), 74-87.

SFS 2008:263. Fjärrvärmelagen.

Sovacool, B. K. (2014). What are we doing here? Analyzing fifteen years of energy scholarship and proposing a social science research agenda. Energy Research \& Social Science, 1, 1-29. DOI: http://dx.doi.org/10.1016/j.erss.2014.02.003

SOU. (2011). Fjärrvärme i konkurrens: betänkande - SOU 2011:44. Retrieved from Stockholm:

Summerton, J. (1992). District heating comes to town: The social shaping of an energy system. (Ph.D.), Linköpings Universitet, Linköping. (Linköping Studies in Arts and Science Nr 80)

Summerton, Jane (ed.) (1994). Changing large technical systems. Boulder, CO: Westview Press.

Swedish Energy Agency (SEA). (2014). Summary of energy statistics for dwellings and nonresidential premises for 2013. ES 2015:07.

Werner, S. (2007). Low Carbon District Heat in Sweden. Euroheat \& Power, 4, 20-25. 
Westin, P. \& Lagergren, F. (2002). Re-regulating district heating in Sweden. Energy Policy, $30,583-596$.

Wissner, M. (2014). Regulation of district-heating systems. Utilities Policy, 31, 63-73. doi:http://dx.doi.org/10.1016/j.jup.2014.09.001

Åberg, M., Fälting, L., \& Forssell, A. (2016). Is Swedish district heating operating on an integrated market?-Differences in pricing, price convergence, and marketing strategy between public and private district heating companies. Energy Policy, 90, 222-232. 